\title{
The Relationship between Recruiter Burnout, Work Engagement and Turnover Intention: Evidence from Serbia
}

\author{
Tatjana Ivanovic, Sonja Ivancevic, Milica Maricic
}

\author{
University of Belgrade \\ Jove Ilica 154, Belgrade, Serbia \\ E-mail.tatjana.ivanovic@fon.bg.ac.rs; sonja.ivancevic@fon.bg.ac.rs; milica.maricic@fon.bg.ac.rs
}

cross $^{\text {ref }}$ http://dx.doi.org/10.5755/j01.ee.31.2.24100

\begin{abstract}
Contemporary research on disorders in modern-day work environment marks burnout among employees in different professions as an important disorder with serious consequences. Practice has shown that recruiters are one of the professions frequently facing burnout. The relationship between burnout, work engagement and turnover intention has often been investigated in the literature. However, even though scholars are increasingly interested in these relationships in other professions, there is a growing need for studies evaluating the relationship between the three concepts among human resource $(H R)$ professionals, particularly recruiters. Having this in mind, the aim of this study is to identify, understand and examine the relationship between burnout, engagement and turnover intention of recruiters in Serbia. The data was collected using an online questionnaire within a sample of 100 recruiters in Serbia. Copenhagen Burnout Inventory was used for measuring burnout, UWES-9 for measuring work engagement and TIS-6 for measuring turnover intention. Structural equation modelling (SEM) was used for evaluating the relationships between burnout, turnover intention and work engagement. The results of the research showed that work engagement has a negative impact on burnout and that burnout has a positive impact on turnover intention, while the relationship between work engagement and turnover intention was not confirmed. The correlation analysis confirmed all three examined relationships. The results largely support the findings from the literature for other professions confirming that employees who suffer from a high degree of burnout are more likely to have a turnover intention. Finally, the implications of these results and recommendations for organizations and recruiters themselves to prevent and decrease burnout are discussed. The findings of this study can make a contribution to the specific academic literature on burnout among recruiters and initiate further research on this topic of high interest.
\end{abstract}

Keywords: Recruiter; Burnout; Engagement; Turnover Intention; Copenhagen Burnout Inventory; UWES.

\section{Introduction}

Research on burnout in the workplace has become increasingly important as employers have begun to realize that numerous employees in different professions around the world suffer from burnout syndrome as one of the most serious disorders in contemporary work environment. Although the syndrome was originally examined among "service workers" (including helping professions, such as health care, teaching and social services) (Brackett et al., 2010; Lee \& Ok, 2012; Schaufeli et al., 2009), research has proved that burnout syndrome is applicable to professionals from a variety of work contexts regardless of their job (Schaufeli et al., 2011) thus expanding the concept of burnout to all jobs and professions (Llorens-Gumbau \& Salanova-Soria, 2014).

Practice has shown that recruiters are one of the professions often facing burnout (e.g. De Angelis, 2012; Savage, 2013; Zoromski, 2007; Weeks, 2018), primarily because of the very nature of their job and the duties it includes. A recruiter's job starts with receiving a request to fill in a vacancy and includes preparing a job advertisement, deciding on appropriate recruiting channel, informing the potential candidates, gathering the applications (Maier et al., 2013), conducting interviews etc. often with strict deadlines and limited cost per hire. This is accompanied with daily contacts with different groups of people which lead to emotional drains of recruiters. With all the challenges involved in the hiring process, it makes sense that the recruiters in organizations experience work pressure on a regular basis, which can put a lot of stress on them. Job stress can often leave recruiters feeling overwhelmed and burned-out (Sorgaard et al., 2007) which can eventually lead to turnover of recruiters who cannot bear the pressure anymore.

The relationship between burnout, turnover intentions and work engagement has been empirically recognized (Schaufeli \& Bakker, 2004) and often investigated in the literature (e.g. Lee \& Shin, 2005; Plooy \& Roodt, 2010). Nevertheless, despite an extensive body of the scientific literature about burnout in other professions, there is a lack of research dealing with recruiter burnout as well as its relationship with work engagement and turnover intention among recruiters. To our knowledge there are only few studies investigating burnout among HR professionals (e.g. Santos et al., 2015; Santos et al., 2016; Mustafa et al., 2016; Mustafa et al., 2014), but only one focusing on recruiters (Prusik \& Szulawski, 2019). The majority of burnout literature that include HR professionals deals with their practices used for preventing and reducing burnout of other employees (e.g. Castanheira \& Chambel, 2010), reducing turnover intention or increasing work engagement.

Even though the existence of work related disorders is slowly gaining the awareness of general public through 
education, international health reports that include the Republic of Serbia provide alarming data. Namely, this years' Stada Group Health Report (2019) presented a research which was conducted from November until December 2018, and which included 18,010 respondents from nine European countries (approximately 2,000 people per country) including Serbia. The researched found the highest rates of burnout in Eastern European countries, where Serbia was ranked the $2^{\text {nd }}$ among all surveyed countries, with 66 percent of respondents who have already had a burnout or the feeling of being on the verge of it, while in other countries the numbers were not quite as extreme (Stada, 2019). Nevertheless, the results showed that the rising number of burnout cases is a real alarm signal for almost 70 percent of Europeans surveyed. For 41 percent, this trend shows that there is something wrong in today's working world. This applies particularly often in Serbia (57 percent), which has the highest percentage in this respect. From this data, it may be concluded that not only do the majority of the Serbs perceive that they have already experienced burnout or consider themselves to be in the risk of experiencing it soon, but also more than a half of them perceive that there is something wrong with the working world today. This reason is more than sufficient to investigate burnout more thoroughly and with the appropriate instruments among working professionals of this nation.

Having all this in mind, the present study attempts to address this gap, aiming at identifying, understanding and examining the relationship among burnout, engagement and turnover intention of recruiters, while the findings of this study can make a contribution to the specific and scarce academic literature in this field. In order to achieve these aims the paper firstly explains the recruiters' exposure to stress and burnout, then analyzes the three explored constructs and their mutual relationships, and finally presents the methodology and the results of empirical research.

\section{Recruiters' Work-Related Stress and Burnout}

All helping professions are at increased risk of experiencing burnout (Iwanicki \& Schwab, 1981). Since human resource professionals' jobs, according to Niehouse (1981), primarily involve taking care of people and their problems, he concludes that they are prime candidates for suffering from burnout. Recruitment specialists have a particularly challenging job in comparison to other HR professionals since their daily duties require satisfaction of the different expectations of various groups of people, including clients/managers and candidates (Prusik \& Szulawski, 2019). Their emotional investments into numerous contacts, for example through interviews, may lead to emotional exhaustion and make them susceptible to burnout syndrome (Prusik \& Szulawski, 2019; Ratcliff, 1988). In addition, " as the point of entry for employees, the recruitment function plays a critical role in enhancing organizational survival and success in the extremely competitive and turbulent business environment', (Singh \& Finn, 2003, p.395). This pressure is also increased with the ongoing transformation of HR sector role from an administrative expert to a strategic partner (Wright, 2008).
Moreover, this transformation is accompanied with another one that includes technological innovations that are being introduced in the process of recruiting - ,the recruitment function has been undergoing dramatic changes as a result of information technology (IT)"' (Singh \& Finn, 2003, p.395), which simultaneously require acquiring new skills, which, as a result, intensifies recruiters' stress and increases their turnover intention (Panayotopoulou et al., 2007; Lukaszewski et al., 2008;). Another source of job stress related to this is such employees' potential perception of job losses that will follow the implementation of IT (Singh \& Finn, 2003). Last but not least, it is important so emphasize that, regardless of their specific nature, organizational changes themselves are considered to be one of the key work-related stressor areas (Cousins et al., 2004) and they can contribute to workers' burnout occurrence and even make them leave companies (Maier et al., 2013). In this regard, Maier et al. (2013) are asking two questions - the first being if HR professionals will accept these changes (Wiblen et al., 2010) and the second, whether there will be unintended consequences. Thus, burnout among HR professionals, as one of the potential consequences should be addressed.

However, there is an evident literature gap relating to the occurrence of burnout syndrome among HR workers and recruiters in particular. To our knowledge, the only study dealing with recruiters burnout is "The Relationship Between the Dark Triad Personality Traits, Motivation at Work, and Burnout Among HR Recruitment Workers", (Prusik \& Szulawski, 2019), published in June, 2019, and conducted in Germany - a country which, according to the authors belongs in a group of so-called "WEIRD" countries (Western, Educated, Industrial, Rich, and Democratic) - an acronym that serves as a descriptor for the participants' setting (Haidt, 2012). Prusik \& Szulawski (2019) comment that pan-cultural aspects of such settings of their study cannot be denied and are worthy of being investigated in the future. From this, we might infer that this very setting may provide some of the explanations of Germany's lower burnout rates in comparison to Serbia's in this years' Stada health report. Firstly, developed countries underwent technological transformation of the workplace before this change has transformed the work processes in developing countries (Kamel, 2005), and the ongoing transformation in the latter still might be a potential stressor. Secondly, a great number of intervention programs for burnout prevention on organizational level were implemented in Germany since the beginning of the $21^{\text {st }}$ century (Awa et al., 2010) so that they can decrease employee burnout levels. Thus, it would be significant to investigate more closely and compare the recruiters' burnout risk in a developing country, such as Serbia, and a developed one, such as Germany.

Taking all of the above into account, it is our opinion that recruiters' burnout risk should be tested and that the measures of preventions to this group of Serbian human resources professionals should be proposed if the burnout risk is proven to exist. Combating stressors at work can consequently contribute to employee retention (Griffeth et al., 2000). 


\section{Linkage between Burnout and Work Engagement}

The term "burnout" was introduced in the 1970s and has remained a challenging research focus across a wide range of academic and professional disciplines since. Burnout is usually considered to be a state of complete physical, emotional and mental exhaustion that is the result of prolonged involvement in emotionally demanding and stressful situations (Pines \& Aronson, 1988). It is often emphasized that the crucial component dwells in the ascription of exhaustion and fatigue to specific areas or domains in individual's life, such as work and client work. It represents "a prolonged response to chronic emotional and interpersonal stressors on the job" (Maslach et al., 2001, p.397). The constant stress and anxiety that an individual experiences at the workplace is gradually transferred to their personal life, seriously damaging their health and causing profound psychological problems in the long run. Burnout syndrome was given a code in classification of WHO - 373.0: Burn-out -State of vital exhaustion $\left({ }^{1}\right)$.

Burnout syndrome is predominantly defined by its three dimensions - exhaustion, cynicism, and professional inefficacy, i.e. high level of exhaustion and cynicism, and low level of professional inefficacy (Maslach \& Jackson, 1986). Emotional exhaustion refers to feelings of being overextended and depleted of individual's emotional and physical resources. Workers feel "spent", drained and used up, being left with no source to replenish their energy and face another challenge or help another person in need. Emotional exhaustion makes an essential element of burnout and presents the main individual stress dimension of burnout, frequently followed by physical exhaustion, illness and psychosomatic symptoms (Maslach, 1978). Cynicism, interpersonal dimension of burnout, denotes a negative, antagonistic, or an overly detached reaction to the job, frequently containing a loss of idealism, and often occurring as a response to the developing emotional exhaustion. In the beginning it serves as a self-protection mechanism; however, over time, this kind of detachment can have a dehumanizing effect. Professional inefficacy, the self-evaluation dimension of burnout, refers to a sense of low efficacy at work, often felt as a decline of productivity and competence at work. People develop a growing feeling of inadequacy related to their capability to perform the job well, which can eventually lead them to believe that the only possible outcome of their professional endeavors is failure.

According to Robinson et al. (2004) employee engagement has become a popular and frequently used term which has received much attention in the past two decades, while an increasing literature on the concept can be found in the academic literature. There are many definitions of employee engagement, mostly explaining employee engagement as intellectual and emotional commitment to the company (Richman, 2006; Shaw, 2005). Engagement refers to being psychologically present when occupying and performing a role within an organization (Kahn, 1990, 1992). Rothbard (2001, p. 656) defines engagement as psychological presence which involves attention and absorption, whereby attention refers to "cognitive availability and the amount of time one spends thinking about a role", while absorption "means being engrossed in a role and refers to the intensity of one's focus on a role." Generally, engagement can be defined as a positive affective relationship with the individual's work (Alarcon \& Edwards, 2010). Schaufeli et al. (2002, p. 74) define engagement "as a positive, fulfilling, work-related state of mind that is characterized by vigor, dedication, and absorption". In their opinion, vigor is a positive emotional state which refers to high levels of energy, mental resilience and persistence in one's work. Dedication is experienced when the individual recognizes his/her work as inspiring and important, feels enthusiastic and takes pride of it. Absorption refers to being entirely focused, deeply immersed and happily occupied in one's work, through which the individual finds it difficult to detach of what he/she is working.

Both burnout and work engagement are related significantly with employee health and organizational performance (e.g. Christian, Garza, \& Slaughter, 2011; Taris, 2006). Researchers have been paying a lot of attention to the burnout - work engagement continuum. According to Schaufeli et al. (2002) the construct of engagement was created having burnout in mind. However, having in mind that these two concepts are highly correlated (Halbesleben, 2010), the relationship between burnout and work engagement has generated debates in the academic literature.

Initially, burnout researchers defined work engagement as the opposing or positive antipode of burnout (Maslach \& Leiter, 1997; Maslach et al., 2001). According to Maslach and Leiter (1997), burnout occurs when work engagement declines, while dedication, vigor and absorption transform into dimensions of burnout as defined by Maslach (1986) exhaustion, cynicism and inefficacy, respectively. Burnout is claimed to be the erosion of these constructs, while engagement refers to their strengthening. Work engagement is 'characterized by a high level of energy and strong identification with one's work', while burnout is 'characterized by the opposite: a low level of energy combined with poor identification with one's work' (Schaufeli \& Bakker, 2003, p. 5). According to this standpoint, Gonzalez-Roma et al. (2006) and Schaufeli \& Salanova, (2007) have found that the core dimensions of burnout and work engagement represent opposites of each other. Having this in mind, burnout and work engagement can be treated as co-dependent and inseparable constructs that are to a certain extent negatively correlated (e.g. Schaufeli, Salanova, Gonzalez-Roma, \& Bakker, 2002; Schaufeli \& Bakker, 2004).

However, subsequent research demonstrated that burnout and work engagement are different concepts that describe related but distinct forms of employee well-being (Schaufeli \& Salanova, 2014). For instance, when an individual does not suffer from burnout, it does not necessarily mean that they are engaged in their work (Schaufeli \& Salanova, 2011). Some employees may experience engagement and feel burned-out simultaneously

${ }^{1}$ International Statistical Classification of Diseases and Related Health Problems 10th Revision (ICD-10)-WHO, https://icd.who.int/ 
or within a short span of time (Timms et al., 2012). For example, if a person's work make them feel emotionally depleted once a week, it does not automatically mean that they will not burst with energy in the same week (Schaufeli $\&$ Bakker, 2004). Seen from this perspective, engagement and burnout are autonomous states which, in view of their opposed nature, are considered to be negatively correlated (Schaufeli \& Bakker, 2004). Moreover, research has confirmed that burnout and work engagement are separate constructs (Denton, Newton, \& Bower, 2008; Schaufeli \& Bakker, 2004; Schaufeli et al., 2002; Schaufeli, Taris, \& van Rhenen, 2008; Hakanen \& Schaufeli, 2012; Langelaan et al., 2006; Duran, Extremera, \& Rey, 2004), greatly interrelated, but essentially different and, for that reason, not just two antipodal ends of one continuum. To conclude, instead of seeing them as two opposing poles, engagement and burnout should be treated as independent, but negatively related constructs. (Schaufeli \& Bakker, 2004). In this paper we take this perspective by using different instruments for measuring burnout and engagement. Considering this, the following hypothesis was defined:

$H_{1}$ : Burnout and work engagement are negatively related among recruiters.

\section{Linkage between Burnout and Turnover Intention}

The predecessors and outcomes of work burnout have been thoroughly examined (Demerouti et al., 2001; Kim, Shin, \& Swanger, 2009) and burnout has been associated with different negative responses to the job (Schaufeli \& Enzmann, 1998) including different forms of job withdrawal. Job withdrawal may have different forms including turnover intention, actual turnover and absenteeism (Leiter \& Maslach, 2009).

Employee turnover describes the phenomena of employees leaving organizations on a voluntary basis (Shaw et al., 2005). By definition, it represents the termination of a person's employment with an organization (Tett \& Meyer, 1993; Allen, Bryant, \& Vardaman, 2010). Employee turnover entails superfluous financial and non-financial costs that may cause a detrimental effect on the organization's performance, especially when competent and experienced employees leave an organization voluntarily (Lingard, 2003). Although all employees' turnover intentions to leave the organization may not always lead to turnover behaviour, research has shown that employees' intention to leave the current job is the best predictor of actual turnover (Griffeth, Hom, \& Gaertner, 2000); Mobley, Horner \& Hollingsworth, 1978; Firth et al., 2004; Tett \& Meyer 1993; Chang et al., 2013).

The issue of turnover intention is a popular topic of research in the field of human resource management, primarily having in mind that an employee's turnover is costly for both individuals and organizations (Lee et al., 2004; Dess \& Shaw, 2001; Karatepe \& Ngeche, 2012). Turnover intention refers to an employee's thinking of leaving the organization in the future (Tett \& Meyer, 1993) or the probability that the employee will stay within the organization (Ciftcioglu, 2011). Blau (2007) defines it as individuals' intent to withdrawn from their occupation/ organization and look for other job or other career alternatives.
A number of studies have suggested that burnout causes considerable costs for both employees and companies because of different factors, including high employee turnover (e.g., Jackson \& Maslach, 1982; Leiter, 1988). A number of empirical studies have demonstrated the positive correlation between turnover and job burnout (Cordes \& Dougherty, 1993; Lee \& Shin 2005; Maslach et al., 2001; Jung \& Kim, 2012).

Increased turnover intention is likely to appear as a consequence of burnout (Kahill, 1988). Numerous studies have found a positive relationship between job burnout and employees' turnover intentions in diverse settings and occupations (Babakus, Yavas, \& Ashill, 2010; Zhang \& Feng, 2011; Scanlan \& Still, 2013; Schaufeli \& Bakker, 2004; Du Plooy \& Roodt, 2010; Choi et al., 2012; Laschinger \& Fida, 2014; Leiter \& Maslach, 2009; Geurts, Schaufeli, \& De Jonge, 1998; Fogarty et al., 2000; Lu \& Gursoy, 2013; Oyeleye et al., 2013; Jackson \& Maslach, 1982; Lee \& Ashforth, 1996; Singh et al., 1994; Cropanzano, Rupp, \& Byrne, 2003; Jones, Norman, \& Weir, 2010; Lingard, 2003). These studies showed that the intention to leave the job is more likely to occur for the individuals that have a high degree of burnout syndrome in a large number of professions (Huang, Chuang, \& Lin, 2003; Shimizu, Feng, \& Nagata, 2005). There is only a small number of research showing that the relation between turnover and burnout is week, but they imply the negative consequences for both the remained burned-out employees and their organizations (e.g. Schaufeli \& Buunk, 2003). Therefore, the following hypothesis was defined:

$\mathrm{H}_{2}$ : Burnout is positively related to turnover intention among recruiters.

\section{Linkage between Work Engagement and Turnover Intention}

A turnover intention, thinking of resigning and intending to look for another job, is a job-related consequence of burnout and engagement (Alarcon \& Edwards, 2010). Engagement, related to employees' positive experiences and emotions, is supposed to enhance positive work-related behavior, including increased job satisfaction (Saks, 2006), better job performance (Sonnentag, 2003), greater attachment to organization and lower tendency to leave the organization (Schaufeli \& Bakker, 2004). Engaged employees often find it difficult to separate from their jobs for they have made great investment in their organization, which may lead to decreased turnover intentions (Alarcon \& Edwards, 2010). Having this in mind, we set the following hypothesis:

$\mathrm{H}_{3}$ : Work engagement is negatively related to turnover intention among recruiters.

\section{Methodology}

To accept or reject the hypotheses, we opted to use structural equation modelling (SEM). The SEM analysis gained in popularity as it lies on principles of factor analysis and regression or path analysis (Stein, Morris, \& Nock, 2012). On one side, it can reduce the dimensionality of the observed phenomenon, while at the same time, it provides information on the relationship between the newly formed, 
latent, variables or constructs. The analysis invokes a measurement model that defines latent variables using one or more observed, measured variables, and a structural model that imputes relationships between latent variables. Due to the above-stated benefits, the SEM analysis became a commonly used statistical analysis for the evaluation of the plausibility of a hypothesized model (Guarino, 2004).

The question which arises when conducting the SEM analysis is how to determine whether the data fir the proposed model. To do so, here we used the Chi-square statistics, Root mean square error of approximation (RMSEA), Comparative fit index (CFI) and Tucker-Lewis Index (TLI). The Chi-square statistics measured the magnitude of discrepancy between the sample and fitted covariances matrices (Li-tze Hu \& Bentler, 1998). A model which has a good fit to the collected data should provide an insignificant result on the 0.05 level. Nevertheless, this rarely occurs as the Chi-square statistics is sensitive to sample size (Hooper, Coughlan, \& Mullen, 2008). The RMSEA indicates how well the model fits the population's covariance matrix (Kline, 1998). Hooper et al. (2008) state that a model has good fit if RMSEA is below 0.06. The CFI compares the fit of the proposed model to the fit of the model in which the constructs are uncorrelated (Bentler, 1990). Values of CFI range from 0 to 1 and values above 0.9 are observed as good model fit (Hooper et al., 2008). The TLI observes the discrepancy between the chi-squared value of the hypothesized model and the chi-squared value of the null model. Values of TLI above 0.9 are interpreted as good model fit (Li-tze Hu \& Bentler, 1999).

So far, SEM analysis has been used with much success in exploring the relation between burnout, turnover intention and work engagement in different professions. For example, Chong and Monroe (2015) observed the impact of the antecedents and consequences of job burnout on junior accountants' turnover intentions. Van Bogaert et al. (2009) analyzed the same, but among nurses, while Kim and Lee (2009) studied burnout, turnover intention and supervisory communication among social workers. In a more recent study, Mansour and Tremblay (2018) set out to analyze job stress, burnout and intention to leave within the hotel industry. Led by the good results in the studies mentioned above, we also used the SEM analysis in our research.

\section{Measures}

Burnout. Even though the Maslach Burnout Inventory (Maslach and Jackson, 1986) remains the most widely used instrument to measure burnout in the scientific literature, the present study utilizes a the Copenhagen Burnout Inventory (CBI) developed by Kristensen et al. (2005) for several reasons: $\mathrm{CBI}$ is freely accessible instrument that is psychometrically robust and extensively applicable to a large scope of professions including various types of client work (Santos et al., 2015).

The CBI has three subscales to evaluate each dimension of burnout, including Personal burnout, Work-related burnout, and Client-related burnout. Being the nucleus of the burnout construct, Personal burnout indicates the state of prolonged psychological and physical exhaustion. Workrelated burnout refers to the state of prolonged psychological and physical exhaustion that is recognized by the individual as connected to his/her work. Client-related burnout refers to the state of prolonged psychological and physical exhaustion that is observed by the individual as connected to his/her work or clients.

Work engagement. The Utrecht Work Engagement Scale UWES-9 (Schaufeli et al., 2006) was used to measure work engagement in this study. According to Mills et al. (2012) UWES-9 is probably a better to use measure of Schaufeli et al.'s (2002) original longer UWES-17. It has been validated in several countries (e.g., Schaufeli et al., 2002; Schaufeli \& Bakker, 2004; Storm \& Rothmann, 2003; Yi-Wen \& Yi-Qun, 2005). UWES-9 consists of three subscales: Dedication, Vigor, and Absorption (Schaufeli, et al., 2006). All items were scored on a seven-point rating scale from 0 (never) to 6 (always).

Turnover intention. Turnover intention was measured with TIS-6 which was found by Bothma \& Roodt (2013) to be a reliable and a valid scale for measuring turnover intention. It consists of five items, and all items are scored on a five-point rating scale from 1 to 5 .

\section{Sample}

The online survey was created and distributed in February and March 2019 as a part of more comprehensive research that included the influence of demographic variables on recruiter burnout. The potential respondents were contacted via e-mail. The completed surveys were analyzed using statistical software SPSS 22 and AMOS 22. The survey contained four major sections: Demographic information, Copenhagen Burnout Inventory, Work engagement scale, and Turnover intention scale. The first section aimed to measure the basic demographic information such as gender, age, country of residence, and work years as a recruiter. Values of specific burnout and work engagement dimensions were measured as mean values of the items which consist include them.

We decided to send our questionnaire to 315 recruiters that we contacted via e-mail. In total, we received 100 responses (response rate was $31.75 \%$ ). Having in mind that the relevant sample for all HR professionals (not only recruiters) in Cranet $^{2}$ research (CRANET, 2015), as the largest one conducted in this country in the field of HRM, was 874 (from 158 private and public sector organizations analyzed), as well as the fact that there are less than 3000 recruiters present on Linkedin working in Serbia (including recruiters, sourcers, talent acquisition specialists and freelance recruiters), we concluded that the sample of 100 recruiters or professionals involved in the process of recruiting would be appropriate and relevant for this research. We observed gender discrepancy as we had 77 female and 23 male recruiters. The mean age of the covered

\footnotetext{
${ }^{2}$ Cranet is an international network of over 40 universities and business schools coordinated by Cranfield School of Management, which conducts a regular international comparative survey of organizational policies and
} has been a Cranet member since 2007, and the latest report was published in 2015. 
recruiters is 33.41 with the standard deviation of 6.997 , while the age range is from 22 to 53 . The respondents have a mean experience of 6.040 years in recruiting with a standard deviation of 4.726 . It can be concluded that our sample covered predominantly young recruiters who already have previous experience in the field.

One of the suggested pre-tests of the SEM analysis is the inspection of the reliability of the proposed scales. Namely, the internal consistency, the level up to which the proposed items (questions) measure the same concept, should be measured (Tavakol \& Dennick, 2011). The most commonly used metric for internal consistency is the Cronbach's alpha (Cronbach, 1951) which takes values from 0 to 1 . The lower bound of 0 indicates that there is no internal consistency, while 1 indicates the opposite. There has been debate on the acceptable values of the Cronbach's alpha (Nunnally \& Bernstein, 1994). According to Tavakol and Dennick (2011), values between 0.70 and 0.95 are acceptable.

We obtained the Cronbach's alpha in two levels: per scale and latent construct (Table 1). On the level of scales, the internal consistency ranges from 0.711 (Turnover intention) to 0.969 (Dedication). All alphas are above the 0.7 threshold, indicating that all scales are consistent. We can observe that the internal consistency of the scales is high although some scales consist of just three items. In the next step, we obtained Cronbach's alpha per latent construct. On the level of constructs, the internal consistency is 0.928 (Work engagement) and 0.910 (Burnout). The conclusion of the analysis is that the data is suitable for the SEM analysis.

Cronbach's Alfa per Scale and Latent Construct with the Number of Items per Scale

Table 1

\begin{tabular}{|c|c|c|c|c|c|c|c|}
\hline & \multicolumn{3}{|c|}{ Burnout } & \multicolumn{3}{c|}{ Work engagement } & Turnover intention \\
\hline & Personal & Work & Client & Dedication & Vigor & Absorption & $/$ \\
\hline Items & 5 & 7 & 6 & 3 & 3 & 3 & 6 \\
\hline$\alpha$ (scale) & 0.926 & 0.869 & 0.957 & 0.969 & 0.907 & 0.920 & 0.711 \\
\hline$\alpha$ (construct) & \multicolumn{3}{|c|}{0.910} & \multicolumn{5}{c|}{0.928} & $/$ \\
\hline
\end{tabular}

\section{Results}

Our initial model aimed to inspect how Work engagement impacts Burnout and Turnover intention, and how Burnout influences Turnover intention. The proposed model and the hypotheses are presented in Figure 1.

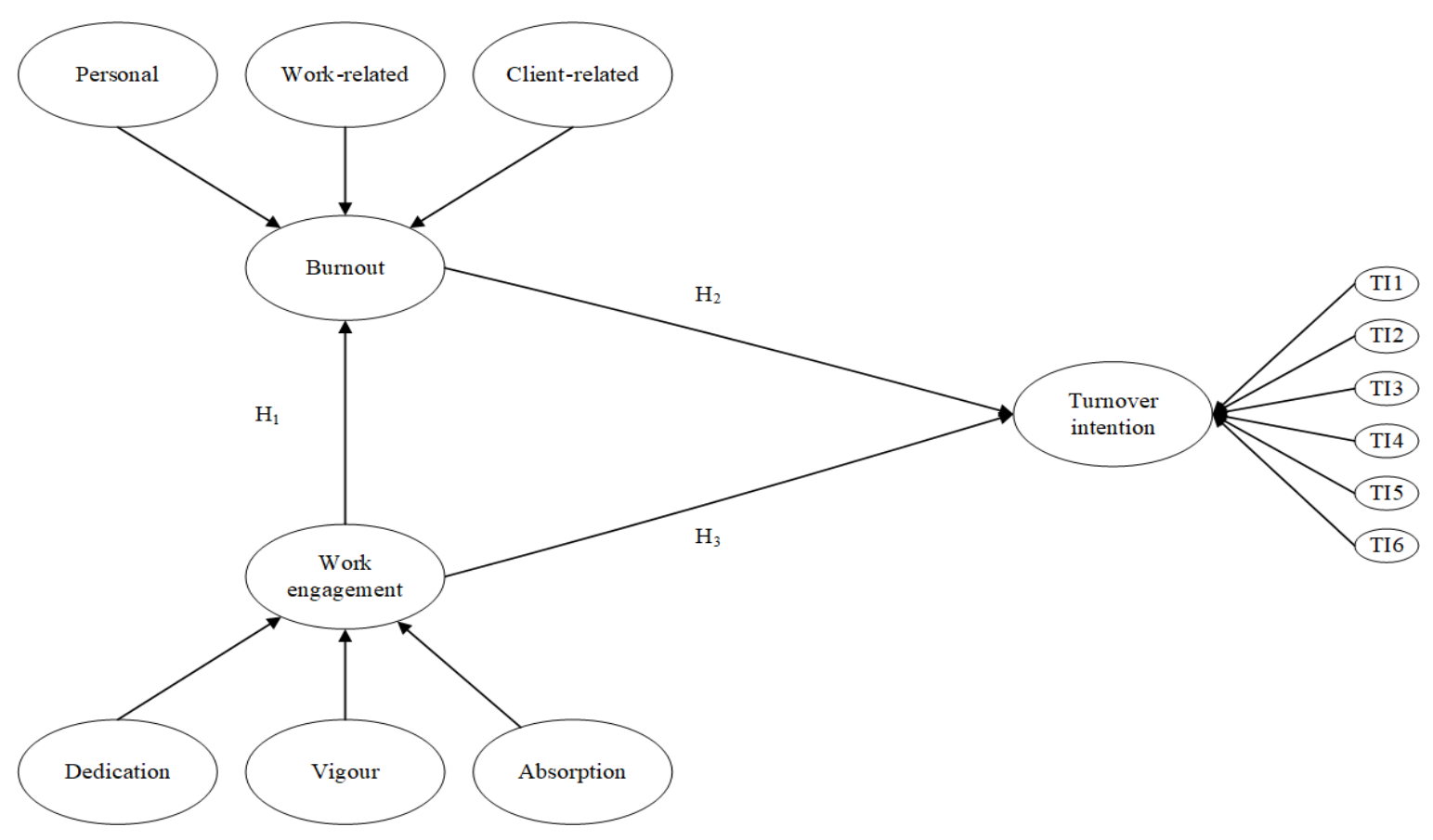

Figure 1. Proposed Model

The initial model had relatively poor fit to the data (Chisquare $=164.415, \quad \mathrm{df}=51, \quad \mathrm{p}<0.000, \quad \mathrm{RMSEA}=0.150$, $\mathrm{CFI}=0.855$, TLI=0.779). Therefore, in order to modify our model, we removed the insignificant paths and variables from the model and used modification indices. The significance of paths was measured using the critical ratio (C.R), whereas C.R. above 1.96 in absolute values indicates a statistically significant path. Only one variable proved to be insignificant, "How likely are you to accept another job at the same compensation level, should it be offered to you?" with C.R. of 0.261 . Also, we found no statistically significant impact of Work engagement on Turnover intention (C.R. $=0.620$ ). The final model had a better fit to the data (Chi-square=69.878, $\mathrm{df}=38, \quad \mathrm{p}<0.000$, RMSEA $=0.092, \mathrm{CFI}=0.958$, TLI=0.926). The assessment of the outer model is given in Table 2 . 
Taking a closer look at the model of Burnout, it can be concluded that Work engagement has a statistically significant negative impact on Burnout. The value of the standardized regression coefficient is 0.442 in absolute value indicating a moderate effect. Work engagement explains $19.5 \%$ of the variability of Burnout. Having in mind that Burnout has just one predictor, we can say that the obtained model is of satisfactory quality. The model of Turnover intention is of similar quality as $20.5 \%$ of its variability can be explained through Burnout. Burnout has a positive impact on Turnover intention, indicating that increased burnout increases turnover intention.

Table 2

\section{Assessment of the Outer Model}

\begin{tabular}{|c|c|c|c|}
\hline Latent construct & Determinant(s) & Standardized regression coefficient & C.R. \\
\hline Burnout $\left(\mathrm{R}^{2}=0.195\right)$ & Work engagement & $-0.442 * *$ & -4.533 \\
\hline Turnover intention $\left(\mathrm{R}^{2}=0.205\right)$ & Burnout & $0.453 * *$ & 4.167 \\
\hline
\end{tabular}

To additionally explore the created model, we inspected the inner models; each latent variable. The assessment of the inner models is given in Table 3. Within latent variables, the regression coefficient of one variable must be fixed and therefore, it is not tested for statistical significance. Accordingly, the C.R. cannot be obtained. Within Burnout, all three types of burnout have positive standardized coefficients and are statistically significant. As expected, the relationship is such that if each type of burnout increases, the burnout increases. The standardized regression coefficients within burnout range from 0.823 to 0.969 , indicating that there is a balance in the impact of different types of burnout on the overall burnout. Analyzing the latent construct Work engagement, again, all coefficients are positive and statistically significant, meaning that the rise of each dimension will increase the overall work engagement. Finally, in the model of Turnover intention, contrary to the previous two latent constructs, imbalance in the importance of items is detected. Namely, the coefficients vary from 0.433 (TI5) to 0.906 (TI3). An overall assessment of the inner model indicates that all coefficients are statistically significant and positive, with high loadings. This indicates that the latent constructs are well constructed (Allen et al., 2019).

Table 3

Assessment of the Inner Models

\begin{tabular}{|c|c|c|c|}
\hline Latent construct & Determinant(s) & $\begin{array}{l}\text { Standardized regression } \\
\text { coefficient }\end{array}$ & C.R. \\
\hline \multirow{3}{*}{ Burnout } & Personal burnout & 0.909 & I \\
\hline & Work-related burnout & $0.969 * *$ & 15.333 \\
\hline & Client-related burnout & $0.823 * *$ & 8.570 \\
\hline \multirow{3}{*}{ Work engagement } & Dedication & 0.986 & 1 \\
\hline & Vigor & $0.799 * *$ & 12.039 \\
\hline & Absorption & $0.922 * *$ & 18.162 \\
\hline \multirow{5}{*}{ Turnover intention } & $\begin{array}{l}\text { How often do you dream about getting another } \\
\text { job that will better suit your personal needs? (TI1) }\end{array}$ & 0.769 & I \\
\hline & $\begin{array}{c}\text { How often are you frustrated when not given the } \\
\text { opportunity at work to achieve your personal work- } \\
\text { related goals? (TI2) }\end{array}$ & $0.720 * *$ & 7.096 \\
\hline & $\begin{array}{c}\text { How often have you considered leaving your job? } \\
(\mathrm{TI} 3)\end{array}$ & $0.906^{* *}$ & 8.585 \\
\hline & $\begin{array}{c}\text { To what extent is your current job satisfying your } \\
\text { personal needs? (reversed) (TI5) }\end{array}$ & $0.433^{* *}$ & 4.654 \\
\hline & $\begin{array}{c}\text { How often do you look forward to another day at } \\
\text { work? (TI6) }\end{array}$ & $0.634 * *$ & 6.162 \\
\hline
\end{tabular}

Note: $* * p<0.01$, C.R. - critical ratio

To additionally scrutinize the model, we obtained the correlation coefficients between the latent variables (Table 4). The correlation coefficients between Work engagement and Burnout and Turnover intention and Burnout are equal to regression coefficients already analyzed previously.
However, it is of interest to observe the correlation coefficient between Turnover intention and Engagement. Namely, the relationship is weak but negative, showing that high work engagement decreases the level of turnover intention.

Table 4

Correlation between Latent Constructs

\begin{tabular}{|c|c|c|c|}
\hline & Burnout & Work engagement & \\
\hline Burnout & 1 & & \\
\hline Work engagement & $-0.442^{* *}$ & 1 & \\
\hline Turnover intention & $0.453^{* *}$ & $-0.200^{* *}$ & \\
\hline
\end{tabular}

Note: $* * \mathrm{p}<0.01$

\section{Discussion and Conclusion}

This study provides a valuable contribution to the literature regarding the relationship of recruiter burnout, work engagement and intention to leave.
The SEM analysis confirmed Hypothesis 1 indicating that work engagement has a statistically significant negative impact on burnout. The obtained result is in line with the previous research of (Schaufeli \& Bakker, 2004; Timms et 
al., 2012; Schaufeli et al., 2008). The results of our analysis confirm the Hypothesis 2, which presumed that burnout has a positive impact on turnover intention. According to the various research, employees who suffer from a high-degree of burnout in different professions are more likely to have a turnover intention. Some of the authors who came to the same conclusion are (Babakus, Yavas \& Ashill, 2010; Zhang \& Feng, 2011; Huang et al., 2003; Shimizu et al., 2005; Cropanzano et al., 2003; Jones et al., 2010; Leiter \& Maslach, 2009; Lu \& Gursoy, 2013). Hypothesis 3, which explored the relationship between work engagement and turnover intention, was not confirmed using SEM analysis. Namely, the obtained coefficient is positive and not statistically significant. To additionally explore the hypotheses, we conducted the correlation analysis. The results of the correlation analysis confirm all three hypotheses. Therefore, we can conclude that the Hypothesis 1 and Hypothesis 2 are confirmed and that the results related to Hypothesis 3 are inconclusive as SEM analysis rejected it, while the correlation analysis accepted it. Our results are partly inconsistent with Du Plooy \& Roodt (2010) whose study confirmed that burnout was significantly positively related to turnover intention of employees in an ICT company, and work engagement was significantly negatively related to turnover intention.

Research has consistently demonstrated that employee burnout has substantial negative consequences both for individuals and organizations (e.g. Bakker \& Demerouti, 2007; Maslach \& Leiter, 1997; Taris \& Schreurs, 2009). Having in mind the strategic importance of recruitment for an organization (Boxall \& Purcell, 2003) and the growing competition in the labor market, the crucial role of recruiters in the overall recruitment process has been recognized by researchers and practitioners (Carless \& Wintle, 2007).

The recruitment industry requires resilience and mental toughness because it has so many variables that cannot be controlled nor predicted. Emotional drains related to recruiters' job make recruiting a tough and stressful job and cause burnout for many recruiters. Once a recruitment professional feels emotionally "spent" and hits the burnout phase, the individual, the organization and the client greatly suffer. Therefore, a lot of attention should be paid to recruiter's well-being.

At the national level, one of the measures that we strongly recommend is that national HR associations (for example, Association of HR professionals of Serbia -
AHRP) implement policies which require recruiters (or professionals involved in recruiting) to be tested once or twice a year using a CBI (or another burnout measuring instrument) in order to measure their burnout level or the risk of its occurrence. Also, recruiters should undergo burnout prevention trainings and develop appropriate mechanisms for burnout prevention.

Comprehending the burnout role may provide management with the guidelines of how to reduce its damaging effects (Elci et al., 2018). For example, companies can provide more frequent shorter holidays as well as more breaks for recruiters during the working days. Allowing recruiters to have more flexible work arrangements, such as flexible working hours or the possibility for telecommuting, as well as creating more positive and fun working environment is always a good way to reduce stress. Companies should also attempt to create such an organizational culture that promotes support, problem sharing and mutual assistance. Providing possibilities for physical activity to the recruiters during the workweek can also increase work engagement and reduce burnout risk. Recruiters themselves should be encouraged to developed coping mechanisms to handle all the negativity that comes with that much failure, huge variation in emotions and disappointment caused by rejections of job candidates faced in their everyday work.

As a consequence, all of these can lead to decrease in recruiters' turnover intention, and help to reduce their actual turnover and related costs.

One of the limitations of this study is the response rate. In this regard we recommend that this research should be expanded with the help of the national HR association that can take part in conducting the study and potentially increase the response rate and the number of participants. Another limitation of the study can refer to the unequal number of male and female respondents.

Possible future directions of the study may involve extending the research to other HR professionals and also to carry out a similar research in other developing countries and compare the results. We also suggest conducting the same research with the use of Maslach Burnout Inventory MBI, in which different burnout dimensions are tested, and thus indicate the most problematic areas identified by both instruments and create an integrated burnout prevention strategy.

\section{References}

Alarcon, G. M., \& Edwards, J. M. (2010). The relationship of engagement, job satisfaction and turnover intentions. Stress and Health, 27(3), e294-e298. https://doi.org/10.1002/smi.1365

Allen, D., Bryant, P., \& Vardaman, J. (2010). Retaining talent: Replacing misconceptions with evidenced based strategies. Academy of Management Perspectives, 24(2), 48-64. https://doi.org/10.5465/amp.24.2.48

Allen, J. et al. (2019). The Role of Critical Incidents and Involvement in Transit Satisfaction and Loyalty. Transport Policy, 75(C), 57-69. https://doi.org/10.1016/j.tranpol.2019.01.005

Awa, W. L., Plaumann, M., \& Walter, U. (2010). Burnout prevention: A review of intervention programs. Patient Education and Counseling, 78(2), 184-190. https://doi.org/10.1016/j.pec.2009.04.008

Babakus, E., Yavas, U., \& Ashill, N. J. (2010). Service Worker Burnout and Turnover Intentions: Roles of Person-Job Fit, Servant Leadership, and Customer Orientation. Services Marketing Quarterly, 32(1), 17-31. https://doi.org/10.1080/ 15332969.2011.533091 
Bakker, A. B., \& Demerouti, E. (2007). The job demands-resources model: state of the art. Journal of Managerial Psychology, 22(3), 309-28. https://doi.org/10.1108/02683940710733115

Bentler, P. M. (1990). Comparative fit indexes in structural models. Psychological Bulletin, 107(2), $238-246$. https://doi.org/10. 1037/0033-2909.107.2.238

Blau, G. (2007). Does A Corresponding Set of Variables for Explaining Voluntary Organizational Turnover Transfer to Explaining Voluntary Occupational Turnover?. Journal of Vocational Behavior, 70(1), 135-148. http://dx.doi.org/10. 1016/j.jvb.2006.07.007

Bothma, C. F. C., \& Roodt, G. (2013). The validation of the turnover intention scale. SA Journal of Human Resource Management/SA Tydskrif vir Menslikehulpbronbestuur, 11(1), Art. \#507. http://dx.doi.org/10.4102/sajhrm.v11i1.507

Boxall, P., \& Purcell, J. (2003). Strategy and Human Resource Management. Industrial \& Labor Relations Review, 57(1). https://doi.org/10.2307/3590989

Brackett, M. A., Palomera, R., Mojsa-Kaja, J., Reyes, M. R., \& Salovey, P. (2010). Emotion-regulation ability, burnout, and job satisfaction among British secondary-school teachers. Psychology in the Schools, 47(4), $406-417$. https://doi.org/10.1002/pits.20478

Carless, S. A., \& Wintle, J. (2007). Applicant attraction: the role of recruiter function, work-life balance policies and career salience. International Journal of Selection and Assessment, 15(4), 394-404. https://doi.org/10.1111/j.14682389.2007.00398.x

Castanheira, F., \& Chambel, M. J. (2010). Reducing burnout in call centers through HR practices. Human Resource Management, 49(6), 1047-1065. https://doi.org/10.1002/hrm.20393

Chang, W. J. A., Wang, Y. S., \& Huang, T. C. (2013). Work design-related antecedents of turnover intention: A multilevel approach. Human Resource Management, 52(1), 1-26. https://doi.org/10.1002/hrm.21515

Choi, S., Cheong, K. K. J., \& Feinberg, R. A. (2012). Moderating effects of supervisor support, monetary rewards, and career paths on the relationship between job burnout and turnover intentions in the context of call centers. Managing Service Quality: An International Journal, 22(5), 492-516. https://doi.org/10.1108/09604521211281396

Chong, V. K., \& Monroe, G. S. (2015). The Impact of the Antecedents and Consequences of Job Burnout on Junior Accountants' Turnover Intentions: A Structural Equation Modelling Approach. Accounting \& Finance, 55(1), 105132. https://doi.org/10.1111/acfi.12049

Christian, M. S., Garza, A. S., \& Slaughter, J. E. (2011). Work engagement: A quantitative review and test of its relations with task and contextual performance. Personnel Psychology, 64(1), 89-136. https://doi.org/10.1111/j.17446570.2010.01203.x

Ciftcioglu, A. (2011). Investigating Occupational Commitment and Turnover Intention Relationship with Burnout Syndrome. Business and Economics Research Journal, 2(3), 109-119. https://doi.org/10.1504/IJAF.2011.043846

Cordes, C. L., \& Dougherty, T. W. (1993). A Review and an Integration of Research on Job Burnout. Academy of Management Review, 18(4), 621-656. http://dx.doi.org/10.2307/258593

Cousins, R., MacKay, C. J., Clarke, S. D., Kelly, C., Kelly, P. J., \& McCaig, R. H. (2004). 'Management Standards' workrelated stress in the UK: practical development. Work \& Stress, 18(2), 113-136. https://doi.org/10.1080/02 678370410001734322

Cronbach, L.J. (1951). Coefficient Alpha and the Internal Structure of Tests. Psychometrika 16(3), $297-334$. http://link.springer.com/10.1007/BF02310555

Cropanzano, R., Rupp, D. E., \& Byrne, Z. S. (2003). The relationship between emotional exhaustion to work attitudes, job performance, and organizational citizenship behaviors. Journal of Applied Psychology, 88(1), 160-169. http://dx.doi.org/10.1037/0021-9010.88.1.160

De Angelis, D. (2012, February 22). Why So Many Recruiters Burn-Out or Fade Away, [Blog post]. Retrieved from https://recruitingblogs.com/profiles/blogs/why-so-many-recruiters-burn-out-or-fade-away

Demerouti, E., Bakker, A. B., Nachreiner, F., \& Schaufeli, W. B. (2001). The job demands-resources model of burnout. Journal of Applied Psychology, 86(3), 499-512. http://dx.doi.org/10.1037/0021-9010.86.3.499

Denton, D. A., Newton, J. T., \& Bower, E. J. (2008). Occupational burnout and work engagement: A national survey of dentists in the United Kingdom. British Dental Journal, 205(7), 1-8. https://doi.org/10.1038/sj.bdj.2008.890

Dess, G., \& Shaw, J. (2001). Voluntary turnover, social capital, and organizational performance. Academy of Management Review, 26(3), 446-456. https://doi.org/10.2307/259187

Du Plooy, J., \& Roodt, G. (2010). Work engagement, burnout and related constructs as predictors of turnover intentions: original research. SA Journal of Industrial Psychology, 36(1), 1-13. https://doi.org/10.4102/sajip.v36i1.910 
Tatjana Ivanovic, Sonja Ivancevic, Milica Maricic. The Relationship between Recruiter Burnout, Work Engagement and...

Duran, A., Extremera, N., \& Rey, L. (2004). Engagement and burnout: Analyzing their association patterns. Psychological Reports, 94(3,Pt1), 1048-1050. http://dx.doi.org/10.2466/PR0.94.3.1048-1050

Elci, M., Yıldız, B., \& Karabay, M. (2018). How Burnout Affects Turnover Intention? The Conditional Effects of Subjective Vitality and Supervisor Support. International Journal of Organizational Leadership, 7(1), 47-60. https://doi.org/10. 33844/ijol.2018.60233

Firth, L., Mellor, D. J., Moor, K. A., \& Loquet, C. (2004). How can managers reduce employee intention to quit? Journal of Managerial Psychology, 19 (2), 170-187. https://doi.org/10.1108/02683940410526127

Fogarty, T. J., Jagdip, S., Gary, K. R., \& Ronald, K. M. (2000). Antecedents and consequences of burnout in accounting: Beyond the role stress model. Behavioral Research in Accounting, 12, 31-68.

Geurts, S., Schaufeli, W. B., \& De Jonge, J. (1998). Burnout and intention to leave among health-care professionals: a social psychological approach. Journal of Social and Clinical Psychology, 17, 341-362. https://doi.org/10.1521/ jscp.1998.17.3.341

Gonzalez-Roma, V., Schaufeli, W. B., Bakker, A. B., \& Lloret, S. (2006). Burnout and work engagement: Independent factors or opposite poles? Journal of Vocational Behavior, 68(1), 165-174. http://dx.doi.org/10.1016/j.jvb.2005.01.003

Griffeth, R. W., Hom, P. S., \& Gaertner, S. (2000). A meta-analysis of antecedents and correlates of employee turnover: Update, moderator tests, and research implications for the next millennium. Journal of Management, 26(3), 463-488. https://doi.org/10.1177/014920630002600305

Guarino, J. (2004). A Comparison of First and Second Generation Multivariate Analyses: Canonical Correlation Analysis and Structural Equation Modeling. Florida Journal of Educational Research, 42, 22-40.

Haidt, J. (2012). The righteous mind: Why good people are divided by politics and religion. New York, NY: Vintage Books.

Hakanen, J.J., \& Schaufeli, W.B. (2012). Do burnout and work engagement predict depressive symptoms and life satisfaction? A three-wave seven-year prospective study. Journal of Affective Disorders, 141(2/3), 415-424. https://doi.org/10.1016/j.jad.2012.02.043

Halbesleben, J. R. B. (2010). A meta-analysis of work engagement: relationships with burnout, demands, resources, and consequences, in A.B. Bakker, M.P. Leiter (Eds.), Work engagement. A handbook of essential theory and research, Psychology Press, Hove, 102-117.

Hooper, D., Coughlan, J., \& Mullen, M. R. (2008). Structural Equation Modelling: Guidelines for Determining Model Fit. Electronic Journal of Business Research Methods, 6(1), 53-60.

Hu, Li-tze., \& Bentler, P. M. (1998). Fit indices in covariance structure modeling: Sensitivity to underparameterized model misspecification. Psychological Methods, 3(4), 424-453. https://doi.org/10.1037/1082-989X.3.4.424

Hu, Li-tze., \& Bentler, P. M. (1999). Cutoff criteria for fit indexes in covariance structure analysis: Conventional criteria versus new alternatives. Structural Equation Modeling: A Multidisciplinary Journal, 6(1), 1-55. https://doi.org/10. 1080/10705519909540118

Huang, I. C., Chuang, C. H. J., \& Lin, H. C. (2003). The role of burnout in the relationship between perceptions of organizational politics and turnover intentions. Public Personnel Management, 32(4), 519-531. https://doi.org/10. $1177 / 009102600303200404$

Iwanicki, E. F., \& Schwab, R. L. (1981). A Cross Validation Study of the Maslach Burnout Inventory. Educational and Psychological Measurement, 41(4), 1167-1174. https://doi.org/10.1177/001316448104100425

Jackson, S. E., \& Maslach, C. (1982). After-effects of job-related stress: Families as victims. Journal of Organizational Behavior, 3(1), 63-77. https://doi.org/10.1002/job.4030030106

Jones, A., Norman, C. S., \& Weir, B. (2010). Healthy lifestyle as a coping mechanism for role stress in public accounting. Behavioral Research in Accounting, 22(1), 21-41. https://doi.org/10.2308/bria.2010.22.1.21

Kahn, W. A. (1990). Psychological conditions of personal engagement and disengagement at work. Academy of Management Journal, 33(4), 692-724. http://dx.doi.org/10.2307/256287

Kahn, W. A. (1992). To be full there: psychological presence at work. Human Relations, 45, 321-349. http://dx.doi.org/10. $1177 / 001872679204500402$

Kamel, S. (2005). The use of information technology to transform the banking sector in developing nations. Information Technology for Development, 11(4), 305-312. https://doi.org/10.1002/itdj.20023

Karatepe, O. M., \& Ngeche, R. N. (2012). Does job embeddedness mediate the effect of work engagement on job outcomes? A study of hotel employees in Cameroon. Journal of Hospitality Marketing \& Management, 21(4), 440-461. https://doi.org/10.1080/19368623.2012.626730 
Kahill, S. (1988). Symptoms of professional burnout: A review of the empirical evidence. Canadian Psychology/Psychologie canadienne, 29 (3), 284-297. http://dx.doi.org/10.1037/h0079772

Kim, H., \& Lee, S. Y. (2009). Supervisory Communication, Burnout, and Turnover Intention Among Social Workers in Health Care Settings. Social Work in Health Care, 48(4), 364-385. https://doi.org/10.1080/00981380802598499

Kim, H. J., Shin, K. H., \& Swanger, N. (2009). Burnout and engagement: A comparative analysis using the big five personality dimensions. International Journal of Hospitality Management, 28(1), 96-104. http://dx.doi.org/10. 1016/j.ijhm.2008.06.001

Kline, R. B. (1998). Software Review: Software Programs for Structural Equation Modeling: Amos, EQS, and LISREL. Journal of Psychoeducational Assessment, 16(4), 343-364. https://doi.org/10.1177/073428299801600407

Kristensen, T. S., Borritz, M., Villadsen, E., \& Christensen, K. B. (2005). The Copenhagen burnout inventory: a new tool for the assessment of burnout. Work \& Stress, 19(3), 192-207. https://doi.org/10.1080/02678370500297720

Langelaan, S. Bakker, A.B., Van Doornen, L.J.P., \& Schaufeli, W.B. (2006). Burnout and work engagement: Do individual differences make a difference?. Personality and Individual Differences, 40(3), 521-532. https://doi.org/10.1016/ j.paid.2005.07.009

Laschinger. H. K. S., \& Fida, R. (2014). New nurses burnout and workplace wellbeing: The influence of authentic leadership and psychological capital. Burnout Research, 1(1), 19-28. https://doi.org/10.1016/j.burn.2014.03.002

Lee, J. H., \& Ok, C. (2012). Reducing burnout and enhancing job satisfaction: critical role of hotel employees emotional intelligence and emotional labor. International Journal of Hospitality Management, 31(4), 1101-1112. https://doi.org/10.1016/j.ijhm.2012.01.007

Lee, K. E., \& Shin, K. H. (2005). Job Burnout, Engagement and Turnover Intention of Dietitians and Chefs at a Contract Food Service Management Company. Journal of Community Nutrition, 7(2), 100-106.

Lee, R. T., \& Ashforth, B. E. (1996). A meta-analytic examination of the correlates of the three dimensions of job burnout. Journal of Applied Psychology, 81(2), 123-33. https://doi.org/10.1037//0021-9010.81.2.123

Lee, T., Mitchell, T., Sablynski, C., Burton J., \& Holtom B. (2004). The effects of job embeddedness on organizational citizenship, job performance, volitional absences, and voluntary turnover. Academy of Management Journal, 47(5), 711-722. https://doi.org/10.2307/20159613

Leiter, M. P. (1988). Burnout as a function of communication patterns. Group \& Organization Management, 13(1), 111128. https://doi.org/10.1177/105960118801300112

Leiter, M. P., \& Maslach, C. (2009). Nurse turnover: The mediating role of burnout. Journal of Nursing Management, 17(3), 331-339. https://doi.org/10.1111/j.1365-2834.2009.01004.X

Lingard, H. (2003). The impact of individual and job characteristic on 'burnout' among civil engineers in Australia and the implications for employee turnover. Construction Management and Economics, 21(1), 69-80. https://doi.org/10. $1080 / 0144619032000065126$

Llorens-Gumbau, S., \& Salanova-Soria, M. (2014). Loss and gain cycles? A longitudinal study about burnout,engagement and self-efficacy. Burnout Research, 1(1), 3-11. https://doi.org/10.1016/j.burn.2014.02.001

Lu, A. C. C., \& Gursoy, D. (2013). Impact of Job Burnout on Satisfaction and Turnover Intention: Do Generational Differences Matter?, Journal of Hospitality \& Tourism Research, 40 (2), 210-235. https://doi.org/10.1177/ 1096348013495696

Lukaszewski, K. M., Stone, D. L., \& Stone-Romero, E. F. (2008). The effects of the ability to choose the type of human resources system on perceptions of invasion of privacy and system satisfaction. Journal of Business and Psychology, 23(3-4), 73-86. http://dx.doi.org/10.1007/s10869-008-9074-0

Maier, C., Laumer, S., Eckhardt, A., \& Weitzel, T. (2013). Analyzing the impact of HRIS implementations on HR personnel's job satisfaction and turnover intention. The Journal of Strategic Information Systems, 22(3), $193-207$. https://doi.org/10.1016/j.jsis.2012.09.001

Mansour, S., \& Tremblay, D. G. (2018). Work-Family Conflict/Family-Work Conflict, Job Stress, Burnout and Intention to Leave in the Hotel Industry in Quebec (Canada): Moderating Role of Need for Family Friendly Practices as 'Resource Passageways. The International Journal of Human Resource Management, 29(16), 2399-2430. https://doi.org/10.1080/09585192.2016.1239216

Maslach, C. (1978). The client role in staff burn-out. Journal of Social Issues, 34(4), 111-124. https://doi.org/10. 1111/j.1540-4560.1978.tb00778.x

Maslach, C., \& Jackson, S. E. (1986). Maslach Burnout Inventory Manual. Consulting Psychologists Press, Palo Alto, CA. 
Tatjana Ivanovic, Sonja Ivancevic, Milica Maricic. The Relationship between Recruiter Burnout, Work Engagement and...

Maslach, C., \& Leiter, M. P. (1997). The Truth about Burnout: How Organizations Cause Personal Stress and What to Do about It. Jossey-Bass, San Francisco, CA.

Maslach, C., Schaufelli, W. B., \& Leiter, M. P. (2001). Job burnout. Annual Review of Psychology, 52, $397-422$. https://doi.org/10.1146/annurev.psych.52.1.397

Mills, M. J., Culbertson, S. S, \& Fullagar, C. J. (2012). Conceptualizing and Measuring Engagement: An Analysis of the Utrecht Work Engagement Scale. Journal of Happiness Studies, 13, 519-545. https://doi.org/10.1007/s10902-0119277-3

Mobley, W. H., Horner, S. O., \& Hollingsworth, A. (1978). An evaluation of precursors of hospital employee turnover. Journal of Applied Psychology, 63(4), 408-414. http://dx.doi.org/10.1037/0021-9010.63.4.408

Mustafa, M., Santos, A., \& Chern, G. T. (2014). Emotion regulation and burnout among Malaysian HR managers: the moderating role of big five personality traits. International Journal of Employment Studies, 22 (2), 79-108.

Mustafa, M., Santos, A., \& Chern, G. T. (2016). Emotional intelligence as a moderator in the emotional labour-burnout relationship: Evidence from Malaysian HR professionals. International Journal of Work Organisation and Emotion, 7(2), 143-164. https://doi.org/10.1504/IJWOE.2016.078091

Niehouse, O. L. (1981). Burnout: a real threat to human resources managers. Personnel, 58(5), 25-32.

Nunnally, B. H., \& Bernstein, J. C. (1994). Psychometric Theory. London, UK: McGraw-Hill.

Oyeleye, O., Hanson, P., O'Connor, N. A., \& Dunn, D. S. (2013). Relationship of Workplace Incivility, Stress, and Burnout on Nurses' Turnover Intentions and Psychological Empowerment. The Journal of Nursing Administration, 43(10), 536542 https://doi.org/10.1097/NNA.0b013e3182a3e8c9

Panayotopoulou, L., Vakola, M., \& Galanaki, E. (2007). E-HR adoption and the role of HRM: evidence from Greece. Personnel Review, 36(2), 277-294. https://doi.org/10.1108/00483480710726145

Pines, A., \& Aronson, E. (1988). Career burnout: Causes and cures. New York, NY, US: Free Press.

Prusik, M., \& Szulawski, M. (2019). The Relationship Between the Dark Triad Personality Traits, Motivation at Work, and Burnout Among HR Recruitment Workers. Frontiers in Psychology, 10, 1290. https://doi.org/10.3389/fpsyg. 2019.01290

Ratliff, N. (1988). Stress and Burnout in the Helping Professions. Social Casework, 69(3), 147-154. https://doi.org/10.1177/104438948806900303

Richman, A. (2006). Everyone wants an engaged workforce how can you create it?. Workspan, 49, 36-39. https://www.wfd.com/PDFS/Engaged\%20Workforce\%20Amy\%20Richman\%20Workspan.pdf

Robinson, D., Perryman, S., \& Hayday, S. (2004). The Drivers of Employee Engagement, Institute for Employment Studies, Brighton.

Rothbard, N. P. (2001). Enriching or depleting? The dynamics of engagement in work and family roles. Administrative Science Quarterly, 46(4), 655-684. http://dx.doi.org/10.2307/3094827

Saks, A. M. (2006). Antecedents and consequences of employee engagement. Journal of Managerial Psychology, 21(7), 600-619. https://doi.org/10.1108/02683940610690169

Santos, A, Mustafa, M., \& Chern, G. T. (2016). The Big Five personality traits and burnout among Malaysian HR professionals: The mediating role of emotion regulation. Asia-Pacific Journal of Business Administration, 8(1), 2-20, https://doi.org/10.1108/APJBA-09-2014-0106

Santos, A., Mustafa, M. J., \& Chern, G. T. (2015). Trait emotional intelligence, emotional labour, and burnout among Malaysian HR professionals. Management Research Review, 38(1), 67-88. https://doi.org/10.1108/MRR-06-20130143

Savage, G. (2013, July 9). This is why recruiters 'burn-out', [Blog post]. Retrieved from https://recruitingblogs.com/profiles/ blogs/this-is-why-recruiters-burn-out

Scanlan, J. N., \& Still, M. (2013). Job satisfaction, burnout and turnover intention in occupational therapists working in mental health. Australian Occupational Therapy Journal, 60(5), 310-318. https://doi.org/10.1111/1440-1630.12067

Schaufeli, W. B., \& Bakker, A. B. (2004). Job demands, job resources and their relationship with burnout and engagement: A multi-sample study. Journal of Organizational Behavior, 25, 293-315. https://doi.org/10.1002/job.248

Schaufeli, W. B., \& Buunk, B. P. (2003). Burnout: An overview of 25 years of research and theorizing. In M. J. Schabracq, J. A. M. Winnubst, \& C. L. Cooper (Eds.), Handbook of work and health psychology (383-425). Chichester: Wiley. https://doi.org/10.1002/0470013400.ch19 
Schaufeli, W. B., Salanova, M., Gonzalez-Roma, V., \& Bakker, A. B. (2002). The measurement of engagement and burnout: A two sample confirmatory factor analytic approach. Journal of Happiness Studies, 3, 71-92. https://doi.org/10. 1023/A:1015630930326

Schaufeli, W., \& Enzmann, D. (1998). The burnout companion to study and practice: A critical analysis. Boca Raton, FL: CRC Press.

Schaufeli, W. B., \& Salanova, M. (2014). Burnout, boredom and engagement in the workplace, in M.C. Peeters, J. de Jonge, T.W. Taris (Eds.), An introduction to contemporary work psychology, Wiley-Blackwell, Chichester (2014), $293-320$.

Schaufeli, W. B., \& Salanova, M. (2011). Work engagement: On how to better catch a slippery concept. European Journal of Work and Organizational Psychology, 20(1), 39-46. https://doi.org/10.1080/1359432X.2010.515981

Schaufeli, W. B., \& Bakker, A. B. (2003). Utrecht Work Engagement Scale: Preliminary Manual, Occupational Health Psychology Unit, Utrecht University, Utrecht. https://doi.org/10.1037/t07164-000

Schaufeli, W. B., Bakker, A. B., \& Salanova, M. (2006). The measurement of work engagement with a short questionnaire: A cross-national study. Educational and Psychological Measurement, 66(4), 701-716. https://doi.org/10. 1177/0013164405282471

Schaufeli, W., \& Salanova, M. (2007). Work engagement: An emerging psychological concept and its implications for organizations. In S. W. Gilliland, D. D. Steiner, \& D. P. Skarlicki (Eds.), Research in social issues in management (Volume 5): Managing social and ethical issues in organizations (135-177). Greenwich, CT: Information Age Publishers.

Schaufeli, W. B., Taris, T., \& van Rhenen, W. (2008). Workaholism, burnout and work engagement: three of a kind or three different kinds of employee well being?. Applied Psychology: An International Review, 57(2), $173-203$. https://doi.org/10.1111/j.1464-0597.2007.00285.X

Schaufeli, W. B., Leiter, M. P., \& Maslach, C. (2009). Burnout: 35 years of research and practice. Career Development International, 14(3), 204-220. https://doi.org/10.1108/13620430910966406

Shaw, K. (2005). An engagement strategy process for communicators. Strategic Communication Management, 9(3), 26-29.

Shimizu, T., Feng, Q., \& Nagata, S. (2005). Relationship between turnover and burnout among Japanese hospital nurses. Journal of Occupational Health, 47(4), 334-336. https://doi.org/10.1539/joh.47.334

Singh, P., \& Finn, D. (2003). The effects of information technology on recruitment. Journal of Labor Research, 24(3), 395408. https://doi.org/10.1007/s12122-003-1003-4

Singh, J., Goolsby, J. R., \& Rhoads, G. K. (1994). Behavioral and psychological consequences of boundary spanning burnout for customer service representatives. Journal of Marketing Research, 31(4), 558-569. https://doi.org/10. $2307 / 3151883$

Sonnentag, S. (2003). Recovery, work engagement, and proactive behavior: A new look at the interface between non-work and work. Journal of Applied Psychology, 88(3), 518-528. https://doi.org/10.1037/0021-9010.88.3.518

Sorgaard, K. W., Ryan, P., Hill, R., \& Dawson, I. (2007). Sources of stress and burnout in acute psychiatric care: inpatient vs community staff. Social Psychiatry and Psychiatric Epidemiology, 42(10), 794-802. https://doi.org/10. 1007/s00127-007-0228-6

STADA (2018). STADA Group Health Report. STADA Arzneimittel AG, www.stada.de.

Stein, C. M., Morris, N. J., \& Nock, N. L. (2012). Structural Equation Modeling. In R. Elston, J. Satagopan, \& S. Shuying (Eds.), Statistical Human Genetics (pp. 495-512). https://doi.org/10.1007/978-1-61779-555-8_27

Storm, K., \& Rothmann, S. (2003). A psychometric analysis of the Maslach Burnout Inventory-General Survey in the South Africa Police Service. South African Journal of Psychology, 33(4), 219-226. http://dx.doi.org/10.1177/ 008124630303300404

Taris, T. W. (2006). Is there a relationship between burnout and objective performance? A critical review of 16 studies. Work \& Stress: An International Journal of Work, Health \& Organisations, 20(4), 316-334. https://doi.org/10.1080/ 02678370601065893

Taris, T. W., \& Schreurs, P. J. (2009). Well-being and organizational performance: an organizational-level test of the happyproductive worker hypothesis. Work \& Stress, 23(2), 120-136. https://doi.org/10.1080/02678370903072555

Tavakol, M., \& Dennick, R. (2011). Making Sense of Cronbach's Alpha. International Journal of Medical Education, 2 , 53-55. http://www.ijme.net/archive/2/cronbachs-alpha/. https://doi.org/10.5116/ijme.4dfb.8dfd

Tett, R. P., \& Meyer, J. P. (1993). Job satisfaction, organizational commitment, turnover intention, and turnover: Path analyses based on meta-analytic findings. Personnel Psychology, 46(2), 259-293. https://doi.org/10.1111/j.17446570.1993.tb00874.x 
Tatjana Ivanovic, Sonja Ivancevic, Milica Maricic. The Relationship between Recruiter Burnout, Work Engagement and...

Timms, C., Brough, P., \& Graham, D. (2012). Burnt-out but engaged: the co-existence of psychological burnout and engagement. Journal of Educational Administration, 50(3), 327-345. https://doi.org/10.1108/09578231211223338

Van Bogaert, P. et al. (2009). Hospital Nurse Practice Environment, Burnout, Job Outcomes and Quality of Care: Test of a Structural Equation Model. Journal of Advanced Nursing, 65(10), 2175-2185. https://doi.org/10.1111/j.13652648.2009.05082.x

Weeks, J. (2017). Why Recruiting is a High Turnover Industry. Retrieved from https://hr.sparkhire.com/staffingindustry/why-recruiting-is-a-high-turnover-industry/

Weeks, J. (2018). 3 Ways to Avoid Recruiting Burnout. Retrieved from https://hr.sparkhire.com/staffing-industry/3-waysto-avoid-recruiting-burnout/

Wiblen, S. L., Grant, D., \& Dery, K. (2010). Transitioning to a new HRIS: the reshaping of Human Resources and information technology talent. Journal of Electronic Commerce Research, 11(4), 251-267. https://ro.uow.edu. au/buspapers/954/

Wright, C. (2008). Reinventing human resource management: business partners, internal consultants and the limits to professionalization. Human Relations, 61(8), 1063-1086. https://doi.org/10.1177/0018726708094860

Yi-Wen, Z., \& Yi-Qun, C. (2005). The Chinese version of Utrecht Work Engagement Scale: An examination of reliability and validity. Chinese Journal of Clinical Psychology, 13(3), 268-270.

Zhang, Y., \& Feng, X. (2011) The relationship between job satisfaction, burnout, and turnover intention among physicians from urban state-owned medical institutions in Hubei, China: a cross-sectional study. BMC Health Services Research, 11, 235. https://doi.org/10.1186/1472-6963-11-235

Zoromski, J. (2007, September 7) Recruiters Are at Risk of Burnout. Retrieved from https://www.ere.net/recruiters-are-atrisk-of-burnout/

The article has been reviewed.

Received in August 2019; accepted in April 2020. 